\title{
J. V. FOIX I LA IRONIA ROMÀNTICA*
}

\author{
J. V. FOIX AND ROMANTIC IRONY
}

\author{
Eberhard GeISLER \\ Romanisches Seminar, Johannes Gutenberg-Universität \\ geisler@uni-mainz.de
}

Resum: L'article es basa en el convenciment que la comprensió usual de la ironia no pot ser aplicada a les obres de J. V. Foix, les quals més aviat han de ser enteses en el context de la ironia romàntica tal com va ser concebuda per Friedrich Schlegel i més tard documentada en la investigació d'Ingrid Strohschneider-Kohrs. Es descriu el terme «reflexió» com l'autonegació de l'absolut per a després analitzar alguns poemes en prosa del poeta, en què tal classe d'ironia pot ser identificada. En els escrits de Foix les freqüents metareflexions sobre poesia o pintura fan aparèixer els textos o els quadres com a il.legibles o dotats d'un gran poder subversiu. Una peça com «El Roc pertús» deconstrueix l'absoluta exemplaritat i arranja un joc d'irònica refracció, la conseqüència final de la qual és un gir antiteològic.

Paraules clau: ironia, ironia romàntica, Romanticisme alemany, Schlegel, Foix, avantguardisme.

Abstract: This paper is based on the assumption that the general conception of irony cannot be applied to the works by J. V. Foix. Instead, they should be considered in the context of Romantic irony as conceived by Friedrich Schlegel, documented in Ingrid Strohschneider-Kohrs' research. After defining the term "reflection" as the self-nihilation of the absolute, this paper analyses some of

$\left(^{*}\right)$ Vull fer constar que aquest treball s'ha beneficiat de l'ajuda del projecte d'investigació del Ministerio de Economía y Competitividad FFI2OI3-4II47-P titulat La ironía en la literatura catalana desde el "Modernisme" hasta 1939. L'estudiós interessat pot consultar el banc de dades bibliogràfic del grup d'investigació sobre estudis d'ironia, paròdia i pastitx en la literatura catalana des de l'inici del segle xx fins a l'actualitat en línia a l'adreça: <http:www.uv.es/ironialitcat>. 
the poet's prose poems, in which this kind of irony can be identified. In Foix's writings, frequent meta-reflections on poetry or painting make texts or paintings appear illegible or endowed with great subversive power. A piece like "El Roc pertús" deconstructs the absolute exemplarity and orchestrates a play of ironic refraction, the final consequence of which is an anti-theological turn.

Key words: irony, Romantic irony, German Romanticism, Schlegel, Foix, Avant-gardism.

\section{Crs es es}

\section{UNA MENA D'IRONIA DIFERENT}

La significació corrent de la ironia és voler dir una altra cosa de la que efectivament es diu, i treure d'aquesta circumstància una mena d'humor. Però, per a parlar de l'obra de Foix, aquest concepte és massa senzill. L'avantguardisme del poeta aquí en qüestió exigeix un altre concepte, unes idees més profundes. Com se sap, l'avantguardisme europeu, del qual Foix forma part, recull idees desenrotllades ja pel Romanticisme alemany. No sabem si el poeta de Sarrià, en efecte, ha llegit textos, per exemple, de Friedrich Schlegel o Novalis. Quan jo el vaig visitar en els anys vuitanta al seu pis en el carrer Setantí a Barcelona, em va dir que l'autor alemany més apreciat per ell era Goethe, és a dir, un representant del classicisme i poc inclinat al Romanticisme. Però cal llegir els textos de Foix, sobretot la seva prosa poètica, per a adonar-se del vincle molt estret que els uneix amb els conceptes romàntics. Per consegüent, cal entendre la ironia en Foix sobretot com a ironia romàntica. Ho veurem tot seguit, amb l'ajuda d'una mostra selectiva d'exemples.

La ironia juga un paper molt important en els escrits dels escriptors i filòsofs alemanys pels voltants de I80o. Podríem citar Jean Paul, Novalis, Ludwig Tieck, Karl Wilhelm Ferdinand Solger o Adam Müller. Però l'autor que probablement més subtilment va reflexionar sobre el fenomen és Friedrich Schlegel. Aquest filòleg parla de la ironia socràtica o de la ironia artística i la defineix com a acte nascut de la llibertat individual. Ingrid Strohschneider-Kohrs escriu en el seu llibre Die romantische Ironie in Theorie und Gestaltung. "la ironia pressuposa la sobirania, elevada i conscient de si mateixa, del Jo que s'autodetermina a la llibertat» (I977: 89). És irònica una consciència que es decideix a una negació la qual per la seva banda serveix per a arribar a un nivell més alt. La negació mena a un grau superior, determinat en la majoria dels casos com a infinitat. El subjecte prova la seva llibertat precisament visant aquesta infinitat. Hi arriba negant-se generalment a si mateix. Schlegel empra de vegades el concepte de la 
parècbasi per a descriure aquesta autonegació. En primer lloc, la parècbasi significa que l'autor d'una narració suspèn la continuïtat i es permet una divagació. En Schlegel, la parècbasi es converteix en una reflexió, i l'autor revela els origens i les condicions de la seva escriptura. Una gran obra d'art és un seguit permanent de parècbasis. Amb això, l'autor es descobreix com a subjecte determinat i limitat, acte que en certa mesura equival a una autonegació. La parècbasi o ironia segons Schlegel preserva el subjecte d'abandonar-se a una autoafirmació massa satisfeta de si mateix. El subjecte irònic aprèn a guardar-ne distància. Així, el filòleg pot formular rotundament: "Allò que no s'anihila a si mateix, no té cap valor» (Strohschneider-Kohrs 1977: 30). I allò que sí que s'anihila a si mateix té el valor de poder dur el lector al món d'allò incondicionat, d'allò absolut i infinit. Schlegel (I972: I2) apunta en un dels seus fragments:

Hi ha poemes vells i poemes moderns que, contínuament en el tot i pertot, alenen l'aflat diví de la ironia. Hi viu una bufoneria realment transcendental. En l'interior una disposició d'esperit que ho abraça tot amb la vista i que s'eleva infinitament sobre tot allò condicionat, s'eleva igualment sobre l'art propi, la virtut o genialitat pròpia: en l'exterior, en l'execució, l'estil mímic d'un bon ordinari buf italià.

I remarca sobre la ironia socràtica (Schlegel 1972: 2I):

Ella conté i excita un sentiment del conflicte indissoluble entre allò incondicionat i allò condicionat, entre la impossibilitat i la necessitat d'una comunicació completa. És la més lliure de les llicències, perquè amb ella hom es sobreposa a si mateix, i al mateix temps és la més conforme a la llei, perquè és absolutament necessària.

El concepte de la ironia és central en Schlegel, i és present també en els seus escrits, encara que l'autor no empra la paraula expressament. Així, llegim una nota sobre les dimensions de l'espiritualitat humana i hi descobrim la mateixa figura de la ironia que consisteix en la coincidència entre l'autolimitació i l'obertura cap a quelcom de més gran. Schlegel (I972: IO) diu:

Qui encara no ha arribat al coneixement clar que hi pot haver una grandesa fora completament de la seva pròpia esfera i per a la qual li manca la sensibilidad absolutament, i qui no té conjectures almenys vagues sobre en quina regió universal de l'esperit humà aquesta grandesa aproximadament pot ésser situada: aquest o no té cap geni en la seva pròpia esfera, o encara no té formació clàssica.

També el concepte de l'enginy humorístic apareix en aquest sentit: «L'enginy humorístic és una explosió d'esperit lligat» (Schlegel I972: I8). Si hom reconeix i supera les pròpies limitacions, hom pot arribar a un ple desplegament de les seves possibilitats enginyoses i còmiques. 
Schlegel anomena la ironia una "facultat filosòfica» (Strohschneider-Kohrs 1977: 32). De fet, les seves consideracions sobre la ironia es troben integrades en la seva argumentació filosòfica general i en la seva envergadura poden ser enteses només des del rerefons d'aquesta. En el centre de la teoria de Schlegel topem amb la figura de la reflexió. El Don Quijote de Cervantes va ser tan important per als romàntics alemanys perquè donava l'exemple modèlic d'una obra d'art basada en la reflexió. D'una banda, Cervantes va parodiar els libres de cavalleries: el seu llibre n'és una versió irònica. A més, va escriure una obra dividida en dues parts, i la segona part resultava una reflexió de la primera. Schlegel va apuntar que Hamlet i Don Quijote, en la seva opinió, són les obres d'art més artificials i de més enteniment precisament perquè estableixen duplicitat. Aquestes obres contenen dues idees i dos elements creadors; es van fer dues vegades, com formula el filòleg. Descriu també el Wilhelm Meister de Goethe com l'obra d'una reflexió i que es sobreposa a si mateixa. Parla dels dos centres que l'obra romàntica necessita; l'el-lipsi, amb els seus dos centres, és el símbol d'aquesta figura. Tant Schlegel com Novalis conceben la reflexió com a autolimitació d'allò absolut. Si l'absolut vol assegurar-se de la seva identitat, ha d'entrar en un procés d'emmirallament, i en aquest procés es perd a si mateix com a instància absoluta. Schlegel conclou: «El món originalment no ha sortit d'un Ou» (Menninghaus 1987: 172); «No hi ha cap punt absolut, cap Ou per a l'univers» (Menninghaus 1987: 89). Al principi ja va haver-hi duplicitat. D'una forma més abstracta, Novalis formula que A es converteix en una equació: $\mathrm{a}=\mathrm{a}$. La diferència de la notació és important: l' $A$ gran es converteix en una $a$ petita. Amb això es realitza l'autolimitació de l'absolut. Davant aquest rerefons teòric, la ironia es revela com a figura d'una divisió que té conseqüències per a la metafísica tradicional. La ironia posa en dubte la identitat absoluta que era signe de Déu. L'escriptor Friedrich Hebbel, que no pertany als romàntics, defineix, això no obstant, l'humor en aquest sentit: "L'humor és una duplicitat que se sent a si mateixa» (1966: 298).

\section{LA VOLUNTAT DE LLIBERTAT}

Lescriptura de Foix - i ens referim a la seva prosa poètica - surt d'una situació semblant a la dels romàntics alemanys. És a dir, també Foix parteix d'una radical voluntat de llibertat. En la seva «Lletra a Clara Sobirós» esbossa un retrat del poeta i apunta que aquest es nega a les convencions burgeses, se n'allibera i vol viure una independència total (Foix 1974: 28): 


\begin{abstract}
No floraleja, ni concurseja, ni vol acontentar les tietes. Si fos prou coratjós i el cofoi aburgesat de tots estaments amb la seva extrema vanitat no li hagués encomanat certes malures, no signaria les obres. Plantaria, a l'hora d'alba, els poemes, com a pasquins, a les parets, o els llançaria des dels terrats. Manifestaria francament el seu desplaer pels grans, pels satisfets, pels asseguts, pels conformats i per les vídues castes i resignades. El poeta sap que cada poema és un crit de llibertat.
\end{abstract}

El poeta, tal com Foix el veu, s'ironitza a si mateix: ja no vol signar els seus poemes, els vol escampar com a pasquins anònims i es limita així com a autor i persona individual. El subjecte humà es redueix a si mateix en vista de la il.limitació que és el seu objecte i que pensa propagar. La voluntat de llibertat és, doncs, un trampolí que ajuda a sortir de si mateix i que permet percebre l'altre. En última instància —i en veurem alguns exemples - aquesta porta a un comiat de la metafísica tradicional. Aquell qui fa de la llibertat un principi central s'allunya de la idea d'una presència absoluta. Amb això, la ironia arriba al cim del seu desplegament.

Hem vist que els romàntics ensenyaven la conjunció entre la reducció i allò incondicionat: si l'home s'autolimita, pot arribar a evocar la infinitat. Foix mostra una conjunció semblant quan parla d'objectes deteriorats que, nogensmenys, serveixen per a recordar allò que no té cap restricció i que és il.limitat. El cas més clar d'una demostració en aquest sentit el dóna el seu text «Nosaltres, els col-lectors de camions a 40 l'hora», contingut en Tocant a mà. El poeta parla de gent que té com a entreteniment particular col-leccionar vells bidons que troben pertot arreu. Els agraden més quan son molt usats, bonyeguts, esbotzats i coberts de ronya. I això perquè precisament en la seva deterioració poden evocar l'eternitat. Foix constata (2004: 889-89I), pensant en els rastres que deixen els usos diferents dels bidons:

La benzina, el petroli, els olis minerals no s'assemblen gens al vi, al blat o a l'oliva. D'ací que l'engrut i la ronya dels bidons els doni singularitat, i que el verdet i el rovell amb què s'adornen de vells els faci atraients als emotius descordats d'avui...

El bidó arriba així a equivaler a una obra d'art digna de ser exposada en un museu perquè obre un espai infinit (Foix 2004: 89I):

Un bidó és una peça de museu si, solitari en un camp segat de poc, en una pista de tennis acabada de polir, en una autopista estrenada de poc, o en una punta de moll al vesprejar d'un port de mar, us commou com si entréssiu a l'eternitat.

Foix no vacil.la pas a comparar l'efecte dels bidons sobre els homes amb quelcom de religiós i místic. No són res, però disposen d'una irradiació metafísica (Foix 2004: 89I): 
De sobte, en un racó del paratge confús va aparèixer un bidó hòrridament solitari. Era d'un vermell brut de greixos consistents. Va ésser per a tots com l'aparició de la Misteriosa Llum al Carme, de Manresa. Era un no-res que provocava o invocava un tot.

El bidó invoca un tot: si bé Foix en unes altres ocasions abandona la metafísica, aquí la conserva, parlant d'una totalitat. De fet, podem trobar en Foix algunes vegades al-lusions al platonisme. Així, el text «Els he cridats tots i cadascun pel nom» acaba amb aquestes paraules: «Us descobriré, més enllà de la muralla i de la frontera, l'ombra de l'Etern i el joc de flames que la nodreix» (Foix 2004: 527). D'altra banda -i és això el que aquí ens cal destacar-, Foix és el poeta català que més distintament ha reprès i desenrotllat la idea de la ironia romàntica.

Un altre text presenta la conjunció entre la reducció d'una persona humana i la seva significació oposada, gairebé transcendent. Es tracta del poema en prosa «Diuen que la filla de l'esclopaire», de L'estrella d'En Perris. El text parla d'una noia boja que camina escabellada, riu sense motiu i dibuixa signes estranys en les parets. Fa ganyotes als conductors dels cotxes de línia i es descorda i aireja el cos quan és a la font de la vila. La gent generalment evita el contacte amb ella: «Diuen que la filla de l'esclopaire, gollut i amb poca feina, és boja, i la gent en fuig quan hi topa» (Foix 2004: 453). Fins i tot sembla tenir trets diabòlics que la situen fora de l'església establerta i de la fe tradicional: «El capellà l'exorcitza quan ella vol entrar al Temple, en dies d'oratge» (Foix 2004: 453). Malgrat tal marginació social i religiosa, el narrador pot descobrir en la noia una capacitat poètica que es revela com a genialitat gairebé sobrehumana. Ella escriu, però cap escriptor té prou talent per a transcriure els seus textos. Són genials, però il.legibles. Es nota aquí la simpatia surrealista envers els bojos, en qui va veure uns portadors de veritat. Foix (2004: 453-455) escriu:

\footnotetext{
M'ha mirat tendrament $\mathrm{i}$, amb timidesa de vestal, m'ha donat un plec de fulls manuscrits on conta, amb lletra segura, clara i torbadora ensems, històries fora d'ús, llunyanes i actuals, que jo, lector llarg de ficccions, no recordo que mai cap escriptor hagi tingut prou talent per a transcriure.
}

Notem que l'autor en aquesta descripció empra paradoxes: la lletra és clara i torbadora ensems, les històries semblen d'un altre temps i són, però, actuals. Aquest ús de paradoxes és senyal també de la ironia romàntica. Schlegel va apuntar: «La ironia és la forma d'allò paradoxal. És paradoxal tot allò que és al mateix temps bo i gran» (1972: 13). 


\section{LA REFLEXIÓ SOBRE L'ART I LA LITERATURA}

Un element irònic important en Foix és la reflexió freqüent de l'art i de l'escriptura. El poeta tracta gustosament de pintura o de literatura i dóna d'aquesta manera un mirall de la seva pròpria activitat creadora. Per exemple, escriu un text que atesta el goig de pintar (Foix 2004: 425), emmirallant així el propi quefer literari. Comença aixì:

\footnotetext{
Ens hem posat, oloroses encara de la bugada, unes bruses de pintor, llargues. Qui millor que jo encerta els blaus per pintar cúpules marianes a la capella del Col-legi? Qui em guanya a preparar els vermells per a imitar el cel ponent en els decorats de la Fugida a Egipte? O els roses insulars per a evocar, amb tret segur, la Naixença de Venus?
}

Una variant d'aquesta reflexió o d'aquest emmirallament es troba en un poema en prosa en què l'autor parla de la seva pròpia poesia. Aquesta al.lusió literària apareix en un context marcat una vegada més per referències a liquiditats apropiades per a pintar. El jo líric i els seus amics enquitranen dues posts velles, i al final es perd amb el seu cavall en una carretera vorejada d'arbres dels quals pengen receptacles de vidre $a m b$ tints. El treball $a m b$ quitrà és una clara referència a la pràctica de l'art. El procediment d'enquitranar no té aquí cap finalitat, cap altre propòsit, que la bellesa. Constitueix un acte merament artístic i sense valor d'ús. A més a més, el color negre en Foix — color del betum- conté un significat de subversió que correspon a la seva concepció general de l'art. En «Quatre colors aparien el món» el poeta descriu el color negre i parla d'unes noies que volen decorar la ciutat amb una allau de cordes enquitranades perquè entenen el color negre com a expressió de força: «A parer d'elles, el quitrà no solament enforteix la vista sinó que la seva flaire, contra el parer d'alguns doctes, té altíssimes virtuts envigoridores i acreix l'energia viril» (Foix I985a: 460). Hi apareix mentrestant el mateix pintor Joan Miró, amic de Foix. És el pintor qui, en el fons, origina aquesta acció decorativa en els carrers. El caràcter subversiu d'aquesta és molt clar: «Vaig comprendre que era ell, En Miró, En Joan Miró del Passatge del Crèdit, qui dirigia aquella arriscada operació embetumadora de franca tendència subversiva» (Foix I985a: 460). I heus ací que Foix (2004: 43I) parla dels seus propis versos. Els han de cremar perquè no els poden interpretar. La pròpia poesia s'ha tornat quelcom d'estrany i il.legible:

Hem arrambat un bidó curull de sal granada al tronc mort de l'alzina que hi ha davant la casa del calderer, a la sortida del passatge. Hem enquitranat dues posts velles bransolejants en tou de ramatges d'eucaliptus i hem calat foc a un manyoc de versos meus que no havíem sabut interpretar. L'Elvira m'ha dit si volia anar a collir glans als Clots. Jo, distret tot mirant com la seva mare encubellava davantals en aigües àcides, i sense dir-li, com cada vespre, adéu, 
he desfermat el cavall, li he embenat els ulls i m'he esgarriat per l'ombra espessa dels arbres que voregen la carretera i dels quals pengen les esferes de vidre on fermenten els tints.

És aquest el tipus d'autoparodia que Schlegel va demanar dels autors de les grans obres d'art. Hi apareix la il.lusió d'un important significat poètic i és negada al mateix temps. La poesia romàntica, conforme a Schlegel, que la veu essencialment representada per Cervantes i Shakespeare, ofereix precisament «aquest meravellós canvi etern entre entusiasme i ironia» (Schlegel 1972: 305). Quan l'alemany tracta la novel.la Wilhelm Meister de Goethe, parla d'aquesta «aparença de dignitat i significació que es burla de si mateixa» (Schlegel 1972: 270). Hi topem també amb la paradoxa de la necessitat de sentit i de la impossibilitat simultània de satisfer-la. Schlegel va constatar la impossibilitat d'una comunicació completa, però nogensmenys en va mantenir la necessitat. El nostre text mostra aquesta paradoxa clarament: Foix confessa la il.legiblitat de la seva poesia, però continua escrivint.

És un tret molt freqüent en la prosa poètica de Foix el fet que el mateix discurs verbal és ironitzat. En el text «Vós sentiu sempre veus pertot» el jo líric diu que sent veus on les altres persones no les perceben, sobretot a la muntanya: «El silenci dels cims és, per a mi, un brogit harmònic de veus» (Foix 2004: 477). On per a la gent normal el discurs emmudeix, per al jo líric uns altres discursos s'obren i es fan audibles. El discurs corrent perd l'aparença de ser absolut, es torna relatiu i ja no pot reclamar la representació de la veritat única i total. S'emmiralla en uns altres discursos i experimenta així una limitació de la seva pròpia pretensió. La veritat es busca també altres camins per expressar-se. El text tanca amb l'advertència que el jo líric porta gravades a les mans les lletres d'un altre alfabet: «Però tinc en privilegi, i de naixença, gravades al clot de les mans, totes les lletres, menys quatre, de l'altre alfabet» (Foix 2004: 477). És interessant veure que en la gravació de l'altre alfabet hi manquen quatre lletres. És conseqüent perquè el procés d'emmirallament produeix una limitació en tots els elements reflectits. Com el discurs original —el dels homes — pateix una manca si és acarat amb un altre, aixíl'altre discurs tampoc no és complet: hi manquen quatre lletres. El conte poètic «L'estació» — publicat juntament amb «Cròniques de l'ultrason»— tracta en primera persona d'un home que fa un passeig i ja al principi topa amb un grup d'uns altres homes que aixequen unes proclames escrites «en lletra fosforescent d'alfabet desconegut» (Foix 1985b: 8I). Poc després es troba davant un barracot ple de llibres, llibrassos i revistes guardats per un ermità. De moment, el narrador pot desxifrar els textos que se li presenten, però aviat s'adona que estan escrits en un alfabet ignorat per ell. Allò que semblava llegible s'ha tornat il-legible (Foix I985b: 87): 


\begin{abstract}
Jo llegia correctament els texts, com si fossin escrits en català d'ara. Acostant-hi la vista, però, va sorprendre'm que les lletres eren d'un alfabet desconegut. Les revistes, gairebé trossejades, dataven també de segles, amb gravats d'época. Les llegia en català, però després, de prop, vaig advertir que estaven compostes en un alfabet ignorat. L'home vestit de parracs d'ermità caminava i somreia. No és pas la primera vegada que m’ha esdevingut això. És més, ara i de temps, en acostar-me, per fullejar impresos, les lletres s'esfumen.
\end{abstract}

Una vegada més presenciem la irrupció d'un altre sistema d'escriptura, d'un altre discurs que posa en dubte el discurs considerat com a original. Tal irrupció la coneix també un text que comença amb la línia «El carter, esmarrit, m’ha donat un plec...", del Diari I9I8 (Foix 2004: 363). El jo narrador relata que rep de les mans d'un carter un plec de cartes. Les ha de lliurar als destinataris. El narrador arriba, de fet, a l'indret que assenyalen les adreces, però ni les cases ni els habitants no hi són, i es troba, al contrari, en un pla boscat. Al final mira de nou les adreces i s'adona que són escrites en la llengua d'aquella contrada i que en desconeix l'alfabet:

El carter, esmarrit, m'ha donat un plec de cartes perquè les lliurés, i m'ha deixat la bicicleta. En arribant, cuitós, a l'indret que assenyalaven les adreces, m'he trobat en un pla boscat. Ençà i enllà, equidistants, clarejaven uns números al capdamunt d'uns pals que, en algun temps, devien haver assenyalat les cases d'un carrer. Un brogit de veus, alternativament joioses i severes, m'ha atret al bruguerar on tampoc no hi havia gent ni hostal. Però en un puig que jo recordava d'haver vist envinyat, senyorejava un mur que m'ha fet creure que em trobava davant un dels casals que cercava. El mur era sol i el portal s'obria a les clarors d'un precipici. Amb un fons de paisatge llunyà, hi havia una taula llarga, en una estança esborronadorament aèria damunt la qual perlejaven vestits de nit, d'home i de dona, capells ornats amb flors acabades de collir, i centenars de copaltes emancipats i supersticiosos. M'ha esglaiat de veure, al fons de tot de la timba, el carter que passava, àgil, per una corda fina tibant entre dos àlbers extrems, i carregat amb un feix de bastons i insígnies autoritaris. He mirat de nou les adreces escrites en el parlar d'aquella contrada, i del qual desconec l'alfabet, i me n'he tornat tot omplint-me les butxaques de pinyols calcigats i polsosos.

De nou trobem una ironització del discurs. És relativitzat, perquè no és la llengua de la contrada susdita i perquè el seu alfabet no és absolut, sinó tan sols una manera d'escriure entre altres, potser moltes. A més a més, Foix ens hi mostra una teoria diferencial del signe. Les adreces remeten a quelcom que no existeix, a una absència. Novalis va concebre així el signe: va apuntar que per a representar allò idèntic cal abandonar-lo, diluint-lo en el procés de la significació. L'idèntic no existeix o, més exactament parlant, es torna un mer signe que remet a una cosa absent (Menninghaus I987: 9I-92). Com hem vist, l' $A$ en majúscula es converteix en $a=a$ en minúscula, si entra en el procés de representació i de reflexió. Si Foix parla d'unes adreces escrites que ja no tenen destinatari, dóna una imatge concreta per a aquesta teoria del signe. 
La ironia romàntica segons Schlegel és constituïda per l'antagonisme entre allò incondicionat i la simultània restricció d'aquest. El text en què el narrador viu una aventura amb un carter escenifica el mateix antagonisme. D'una banda, descriu un discurs relativitzat o limitat en la reflexió; de l'altra, evoca la idea d'allò incondicionat. El narrador conta que descobreix en el paisatge una taula llarga sobre la qual es troben exposats vestits de nit, d'home i de dona, capells ornats amb flors i centenars de copaltes. Aquestes coses estan fora de l'ús que normalment els homes en fan. Tenen la raó de la seva existència en si mateixes, elles mateixes es fonamenten. No és casualitat que els copaltes siguin anomenats «emancipats». La llei de l'ús social ha retrocedit, i les coses mostren la seva pura presència, alliberades de constrenyiments i finalitats. Amb això es dóna el pol d'allò incondicionat que entra en oposició al pol del discurs relativitzat i limitat. És l'antagonisme que els romàntics alemanys van establir com a principi del seu art: romantitzar les coses, segons Novalis, és donar a allò corrent un aspecte misteriós, a allò conegut la dignitat d'allò desconegut, $\mathrm{i}$ a allò finit una aparença d'allò infinit.

La ironia romàntica és un moviment entre dos extrems o contraris. Els pensadors d'aquesta època consideraven la filosofia com el resultat de dues forces en lluita (vegeu Strohschneider-Kohrs 1977: 40). La intuïció de Foix és tan gran que àdhuc ha afegit una imatge bella d'aquesta tensió. El narrador, doncs, al final descobreix el carter «al fons de tot de la timba» balancejant-se sobre «una corda fina tibant entre dos àlbers extrems». Si tenim en compte el context teòric desenrotllat per nosaltres, podem llegir aquesta imatge com a al.lusió a l'alternança permanent entre autocreació i autodestrucció que, segons Schlegel, constitueix l'essència de la poesia. La poesia romàntica s'insereix en una progressió infinita; sempre està esdevenint i mai no està acabada. Amb això, Foix pot passar per precursor d'Antoni Tàpies, que en la seva pintura ha establert la mateixa tensió entre una inclinació cap a les coses modestes i menyspreades com samarretes, cordes, capses de cartró i mitges, d'una banda, i l'evocació d'una latitud mística, de l'altra. Tàpies sempre ha venerat el nostre poeta com a baluard perseverant de l'avantguardisme a Catalunya i ha format un llibre d'artista amb ell (L'estació), en el qual aportava litografies.

Per confirmar la nostra interpretació, citem encara un altre text que igualment pot ser considerat com a escenificació del procés creador. Es tracta de nou de pintura. El text en qüestió comença amb les paraules «En arribant a la Universitat dels Pares». El narrador conta que un dia visita la universitat regida per un orde monàstic. Havia cregut que els monjos eren mercedaris, però per la seva taciturnitat podrien ser de la Trapa. Els religiosos duen el narrador al celler que és el seu taller d'artistes: aquí "pinten damunt retaules vells estructures noves», i quan això està enllestit, esborren la seva 
pintura i hi apliquen nous dibuixos i colors diferents. Una vegada més topem amb el procès romàntic que alterna en destrucció de l'art i la seva nova creació. Aquestes segones pintures evoquen «l'escorça pressentida però oblidada d'un arbust pre-colonial o un aeròdrom en procés d'ossificació», és a dir que reuneixen passat i futur en el moment present de pintar. Heus ací la primera part del text (Foix 2004: 335):

En arribant a la Universitat dels Pares, els monjos que hi viuen, que jo em creia que eren mercenaris, m'han rebut silenciosos com si fossin de la Trapa i m'han acompanyat al celler on, de nit i de dia, pinten damunt retaules vells estructures noves, amb verds i vermells frisosos i blaus enervats. Treuen les colors de tines profundes guardades al fresc de la gruta amb pia gaubança. Enllestits, esborren colors i dibuix, i escaten la taula on, de nou, pinten negres urgents i grocs en aparents concrecions que evoquen l'escorça pressentida però oblidada d'un arbust pre-colonial o un aeròdrom en procés d'ossificació.

Podem constatar la intuició extraordinària de Foix també en aquest cas. Ha situat l'activitat artística en mans de representants d'una institució religiosa que en el seu quefer reuneix la fe i el saber. En principi, el saber és quelcom que posa en dubte la fe. Assistim a un desenrotllament de profunda ambivalència. L'acte de pintar, i això és important, apareix com a acte devot ja que procedeix d'uns monjos que manegen els colors «amb pia gaubança», però té al mateix temps quelcom de diabòlic ja que amb l'altra capa de pintura sobre els retaules vells es fa desaparèixer quelcom de venerable i sant. La pràctica artística dels monjos és, doncs un moviment més enllà de la fe i efectua una limitació d'allò absolut. És irònica. La figura que aquesta ironia descriu és la d'allò que Schlegel va anomenar la filosofia de la poesia: una activitat més alta que la mera poesia, poètica, però superposada a la poesia. Aquesta filosofia de la poesia plana, com formula Schlegel, al dessobre dels gèneres diversos, superantlos cadascun individualment i efectuant la unió de tots. L'oxímoron de la «lúbrica puresa» que deu ser propietat dels colors emprats pels monjos, és un eco de tal figura irònica (Foix 2004: 335-337):

Ebri de les colors i de llur lúbrica puresa, he saltat pel rost cap al camí de la Plana. Hauria exultat i tot en veu alta, si un pagès no m’hagués fet adonar de la boira que s'arrossegava per la bardissa d'En Fornells i de les seves figuracions i arranjaments immediats. L'escopetada d'un caçador furtiu ens ha alliberat de l'encís. He cridat: Negrors! Supersticions! Botiflers! Posseïts! I, de tornada a l'alberg, he esquinçat els gravats que il.lustraven llibres claustrals i antologies floraleres i els he escampat per la cambra dels quitrans transeünts.

En aquest final del text apareix una ironia addicional. El narrador està entusiasmat amb els colors emprats pels monjos, però aviat els acusa de ser supersticiosos i posseïts per esperits dolents, potser diabòlics. I hi ha un tomb insospitat: de seguida relativitza tal distanciament esquinçant, retornat al seu alberg, els gravats de llibres 
monacals i d'antologies poètiques. Segueix d'aquesta manera el joc de relativització i de continuïtat, tan típic de la ironia romàntica. El narrador nega la pràctica artística dels monjos per a continuar-la immediatament. És clar que aquesta pràctica exercida pel narrador com a seguidor dels monjos té un caràcter fortament subversiu. No solament nega testimonis de la tradició cristiana sinó que realitza el seu acte destructiu a la cambra dels quitrans: de nou apareix, junt amb el color negre, el quitrà com a símbol foixià de la pràctica de l'art subversiu. A més a més, aquests quitrans es troben en moviment, són transeünts. La subversió artística és essencialment moviment. Això recorda una vegada més l'ésser de l'art i de la poesia tal com el concebien els romàntics alemanys. Schlegel va escriure; «La ironia és una conciència clara de l'agilitat eterna, del caos infinitament curull, ple a vessar» (Strohschneider-Kohrs 1977: 59). Segons l'exigència de Schlegel, cal idear com a objectiu una expressió que és poètica i filosòfica al mateix temps: la poesia junt amb la poesia de la poesia. El text citat de Foix és admirable precisament per la seva realització conseqüent de la ironia romàntica i per haver-la mostrat en el seu context: el de l'autosuperació de la religió, de la negació de la religió i de la seva afirmació al mateix temps.

L'acte limitador del discurs té una certa recurrència en la prosa poètica de Foix, també on és només un petit detall. Aquest és el cas en un capítol de les "Cròniques de l'ultrason». El narrador es troba de vegades amb una dona per parlar amb ella. Si vol repetir les paraules que ella diu, aquestes són sotmeses a dissolució i desfiguració i obtenen un caràcter imaginari: «Ja m'havia passat alguna altra vegada que, en havent parlat, provava de repetir els mots que m'acabava de dir, però en expressions gairebé quimèriques» (Foix 1985: 47).

\section{LA REFLEXIÓSOBRE ELJO ILA DESCONSTRUCCIÓ D'ALLÒ ABSOLUT}

Si bé en la majoria dels casos el discurs verbal és posat en dubte, també es pot veure que el jo individual entra en un procés de reflexió. És un procés que duplica el jo, combinant l'emmirallament i l'aparició de l'altre. «En Quirc de l'Erminda», de Darrer comunicat, és un text on una persona nomenada En Quirc de l'Erminda ja no es pot veure en el mirall, troba buit l'espill. Quan el narrador al final es mira en el mirall, s'hi troba només «lluny, molt i molt lluny, a la punta d'un llarg passatge que forada els murs, girat d'esquena» (Foix 2004: 625). El mirall nega la reflexió exacta, no mostra la cara del narrador sinó només la seva esquena, i tota la figura empetitida. En el fons del jo ha sorgit un altre que nega ser el mateix. Aquest joc d'emmirallament es troba també de forma inversa. El narrador d'un altre capítol de les «Cròniques de 
l'ultrason» ensopega amb una altra persona i ha d'adonar-se que aquesta és ell mateix i aquí també s'esdevé una pertorbació del concepte d'identitat (Foix 1985b: 34):

De sobte, un personatge a contrallum es presenta davant meu com qui ve a alliberar-me i obre els braços com qui ve a abraçar-me. Jo aconsegueixo amb esforç d'allargar les mans, alço la testa i m'adono que sóc jo mateix.

Foix va molt lluny en la seva representació de processos reflexius, és a dir irònics. Un exemple que voldríem anomenar clàssic en aquest sentit és el conte poètic «El roc pertús», de Darrer comunicat. El text tracta d'una població que venera un petit roc foradat que es troba fora del poble situat dalt un promontori. La gent decideix un dia portar el roc a la ciutat i erigir-lo al bell mig de la plaça. La raó per a ells és que el roc representa quelcom de metafísic. S’hi encarna la totalitat: «El Roc pertús és la representació de la matriu de tots els mons físics realitzats o possibles» (Foix 2004: 667). Té un caràcter transcendent («el poble fabulador i vulgar li atribueix les valors carismàtiques d'un fet sobrenatural», Foix 2004: 667) i gairebé religiós o cristià (el tracten «com si fos una imatge de Maria», Foix 2004: 667). Àdhuc hi ha uns frares que li volen construir un templet. En una paraula: els habitants volen «alliberar el Roc absolut" (Foix 2004: 665). Però de sobte s'esdevé quelcom d'imprevist que canvia el sentit filosòfic del conte. Hi apareix un llarga fila de camions que porten una quantitat enorme de rocs. I hi surt una persona que explica la significació d'aquest succés multiplicador (Foix 2004: 669-67I):

[...] a totes les carreteres i camins que duen a la vila han aparegut centenars de camions carregats de rocs, tot formant llargues cues que es perdien dellà l'enllà, amb un sol camioner amb posats de prior benedictí, el qual en llatí eclesiàstic mal engafetat ha clamat: - Tot roc és absolut per al savi submis i per a l'ardorós solitari. En Roig de Malpèl ha penjat a les sis branques d'un arbre robust i secular, sis vestes amb espessors de gebres endurides i d'herbes gomers. - Tota pedra és suprema per al clarivident i per als saurins de l'ultrason. Tot còdol és prodigiós i tot palet cabdal per a l'home encerclat de grues locomòbils.

D'aquesta manera, Foix efectua la dissolució de l'U idèntic en si mateix. El roc foradat i venerat pel poble ha de perdre el seu paper de representació d'allò absolut. El predicat de Déu — que ell és Déu — està posat en qüestió. Es desenvolupa, en canvi, un procés en què tot còdol, a fi de compte tot objecte, pot ser prodigiós i remetre a allò incondicionat. Tot es torna emmirallament. És un pensament típicament romàntic que concep el cristianisme d'una manera nova i que parcialment el nega. La ironia romàntica supera el cristianisme. En aquest sentit, Schegel va apuntar que moltes coses poden fer de mitjanceres entre l'home i la divinitat, que el Crist no hi és l'únic mitjancer. És una idea que prové en última instància de Spinoza, o sigui una idea panteista (Schlegel I972: 50):

Caplletra 60 (Primavera, 2016), pp. 147-161 
És molt exclusivista i arrogant de creure que hi pot haver només un mitjancer únic. Per a l'home cristià perfecte - i és l'extraordinari Spinoza qui sota aquest aspecte s'acosta a aquest ideal més que ningú- totes les coses deurien ser mitjanceres.

Foix subratlla aquestes idees afegint a l'allau de còdols un altre cas de multiplicació: el de la persona que ha presidit l'acció del poble de traslladar el roc foradat mentrestant ha après de l'home savi i treu les conseqüències penjant-hi sis vestes a les sis branques d'un arbre.

Foix ha mostrat una inclinació al platonisme i ha escrit poemes religiosos en un apartat del seu llibre Sol, i de dol. Això sí. Però la seva prosa poètica és radical i porta el lector finalment a la negació del mateix sentit. En el seu procés de substitucions, la reflexió efectua una pèrdua de la significació. Amb això, Foix fa el pas dels conceptes dels romàntics alemanys cap a la filosofia de Jacques Derrida. Com és sabut, Derrida reprèn idees de Schlegel o Novalis sense esmentar-los (sobre aquestes herències vegeu el llibre mencionat de Winfried Menninghaus). En un capítol de les Cròniques de l'ultrason (Foix 1985b: 74) el narrador recorda un esdeveniment remarcable:

A les fosques, havia tret, del prestatge de la llibreria que recull els clàssics, un llibre que vaig provar de llegir quan ja era al llit. Era un Ovidi en llatí i amb notes fetes a mà, amb estilogràfica, que mostraven les meves inclinacions en la postadolescència. Vaig rellegir-ho. Fatigat, vaig deixar el llibre damunt la vànova. Quan volia recollir-lo, en desvetllar-me, el llibre no hi era. Vaig passar la mà per tot el cobertor: era llis. Però, en recercar-lo, al prestatge més alt de la biblioteca, el llibre havia estat substituït per un exemplar relligat amb luxe de bibliòfil. L'he obert i, a la claror d'una llanterna, he vist que les dues-centes pàgines del llibre eren en blanc. No sabia què pensar.

El narrador agafa un llibre que desapareix de seguida i és reemplaçat per un altre volum amb pàgines blanques. L'emmirallament, en última instància, ha obrat la desaparició del sentit. El logos que en uns altres temps era diví es troba cancel.lat.

Aquesta conseqüència antiteològica ens parla més explícitament encara d'un altre poema en prosa. Prové ja dels primers fragments del Diari I9I8. Aquí, un temple cristià dalt d'un pujol és substituït de sobte per l'estàtua d'un cavall. En lloc de la veneració de Déu, hi senyoreja ara el símbol de les passions corporals per antonomàsia i de l'inconscient. L'emmirallament ha obrat la diferència més radical possible implicada ja des de sempre en la ironia romàntica, és a dir, la negació de Déu (Foix 2004: 219):

Quants de tombs jo havia dat adés per l'exterior dels murs de la catedral bastida dalt el pujol! Aleshores anaves al temple cada dia, cenyit el front de roses, a prendre notes taquigràfiques del sermó de les Set Paraules. Jo, mentrestant, arrossegant un piano de maneta, cercava, àvid, els aparadors on hi havia exposades les divines sabates de xarol o els meravellosos paraigües, invenció dels homes. M'han dit que havies reprès el vell costum i que tornaves cada dia al temple. Però en 
anar-me-n'hi avui, el temple havia desaparegut i al seu lloc, immensament deserta, hi havia, en vidre policrom, una estàtua del meu cavall, que centellejava en tènues rosasses als flancs del pujol.

Hem dit que no sabem si Foix realment ha llegit els romàntics alemanys. Podem constatar, no obstant això, que ha sabut desenvolupar la idea de la ironia amb mestratge i que dóna un exemple molt vigent de l'avantguarda europea que en els seus trets més generals ha reprès conceptes romàntics.

\section{Eberhard Geisler \\ Romanisches Seminar, Johannes Gutenberg-Universität geisler@uni-mainz.de}

\section{REFERÈNCIES BIBLIOGRÀFIQUES}

Forx, J.V. (1974) Obres completes, I, Poesia, Barcelona, Edicions 62.

- (I985a) Obres completes, II, Prosa, Barcelona, Edicions 62.

- (1985b) Cròniques de l'ultrason. L'estació, Barcelona, L'amic de les arts / Quaderns Crema.

- (2004) Diari I9I8, estudi i edició de Joan R. Veny-Mesquida, Barcelona, Institut d'Estudis Catalans.

HebBel, F. (I966) Werke, Iv, ed. de Gerhard Fricke, Werner Keller i Karl Pörnbacher, München, Hanser.

Menninghaus, W. (1987) Unendliche Verdopplung. Die frühromantische Grundlegung der Kunsttheorie im Begriff absoluter Selbstreflexion, Frankfurt/Main, Suhrkamp.

Schlegel, F. (1972) Schriften zur Literatur, ed. de Wolfdietrich Rasch, München, Deutscher Taschenbuch Verlag.

Strohschneider-Kohrs, I. (1977) Die romantische Ironie in Theorie und Gestaltung, Tübingen, Niemeyer. 